\title{
sciendo
}

\section{Regional disparities in the public health care system: Evidence from Romania}

\author{
Silvia-Elena CRISTACHE \\ Bucharest University of Economic Studies \\ csilvia2005@yahoo.com \\ Erika MARIN \\ Bucharest University of Economic Studies \\ erika.marin@csie.ase.ro \\ Daniela SERBAN \\ Bucharest University of Economic Studies \\ danielaserban2002@yahoo.com
}

\begin{abstract}
The European Pillar of Social Rights proclaimed the people's right to access to healthcare facilities and services, irrespective of the geographic residence.

Currently, the health system in Romania has a number of major deficiencies, ranging from the lack of state-of-the-art equipment in some hospitals, inadequate medical staff in many hospital units, to the lack of essential, vital medicines needed for treatments prescribed to the sick.

The paper aims to analyze the differences in the public health care system between the eight development regions in Romania (Northwest, Center, North-East, South-East, South-Muntenia, Bucharest-Ilfov, South-West Oltenia and West) and to identify the reasons that led to their appearance. The paper presents a detailed examination of the main statistical indicators of the public health care system in Romania using a series of statistical analysis techniques. We founded significant differences amongst the eight development regions in Romania, regarding the functioning of the public health care system. Some regions (such as Bucharest Ilfov) is found to outperform others; these regional gaps are analyzed attempting to highlight the main reasons of the regional disparities.
\end{abstract}

Key words: health system, development regions, medical personnel, investments in health, number of beds available in hospitals,

\section{Introduction}

The Romanian health system it cannot be considered one of the best performing health segments in the world, but despite this fact the population must adapt to the conditions and try to find the most efficient and advantageous way to treat each one if necessary. The state of health as well as acces to health system is closely related to the level of the country's economic status reflected in the population's standard of living and working conditions, political factors, environmental factors as well as human related factors (such as genetic factors). That is why a regional profile analysis is important to discover and understand the regional disparities is the access to healts services. In this context, four main goals of the health system could be identified: promoting health in order to actively participate in the 
social life, protecting health in order to maintain it and preventing diseases, ensuring permanent control of morbidity by combating diseases, recovering health through involvement of the whole health system. (http://www.iccv.ro/)

Romania's accession to the European Union required the adoption of the European Health Card. It is issued in the event of the insured person moving for a temporary stay in an EU Member State and covers any medical treatment and emergency care that becomes necessary in accordance with the health system of the respective state. The card is issued at the expense of the insured, by the Health Insurance House to which it is insured. (Major $\mathrm{D}, 2009)$

The current financial crisis has determined both in urban and rural areas, the inability of citizens to access services to which they were entitled, such as: basic medical analysis provided by laboratories, medicines granted compensated or free, in the case of children or serious illnesses. Regarding the perspectives in the field of health in Romania, by the end of 2019 the Ministry of Health intends to finalize new calls in the field of prevention programs, early detection, diagnosis and early treatment of colorectal cancer and for the screening program to identify patients with factors cardiovascular risk, aimed at reducing morbidity and mortality from cardiovascular disease. According to the governmental strategy, "the health care system, with its institutions and health professionals, places the patient at the center of his concerns.

The social concept on which the health system is based is based on the principles of universal access to quality healthcare and, therefore, implies the application of the principle of solidarity in financing."(http://gov.ro/ro/obiective/strategii-politici-programe/sanata te\&page=1\#null)

According to the Report Health status in the EU 2017 elaborated by the OECD and the European Observatory for health systems and policies, an important issue in Romania's profile is access to healthcare, "particularly low in rural areas and is exacerbated by differences in demographic coverage", which makes unmet healthcare needs substantially above the EU average.

The analysis reveals as well a paradox: "While a large part of the population of Romania self-evaluates as enjoying a good health, life expectancy at birth remains with almost six years below the EU average and it is one of the lowest in the EU". (https://ec.europa.eu/romania/news/20172311 profil sanatate state membre si ue ro)

In this context, the Government, through the government program 2018-2020 in the field of public health policies, is committed to support a series of major investments, such as the construction of 8 regional hospitals and a republican hospital in Bucharest, the modernization of the majority of county and hospital hospitals. the specialized ambulatories and emergency units, the endowment of each municipality with ambulances and the adoption of a new Health Law at the latest on December 31, 2018.

Regarding the health infrastructure, the government program 2018-2020 also provides for a number of measures, such as the construction with financing from the FSDI of the 8 regional hospitals, organized as emergency-excellence centers, for all medical specialties, including centers. of regional or national telemedicine, depending on the specialty, to which the medical centers can be connected, both for diagnosis, but also for a second opinion, the cost of a hospital being estimated at 300 million euros. When developing the response capacity for the Ambulance Services and SMURD, through the National Ambulance Equipment Program, it is desired to gradually replace the current ambulance 
park, in addition to the ambulance that will be assigned to each municipality.

Also, the program provides for the development of regional or national telemedicine centers and the operationalization and use of the Patient Electronic File which will contain all the health data and which will be the basis of the National Registers for each pathology.

\section{Literature review}

The evaluation of health services aims to identify vulnerabilities, slippages or strengths and to create the premises of a systemic, integrative, performance-generating approach. In Romania, the health system is subject to a broad process of decentralization that targets the entire public administration. ( Stoina,C.,N.,2012)

Private medical practices represent a relatively small proportion of the total health services, the costs being prohibitive for a large part of the population. In the public domain, Marius Bucă, medical director at SOS Medical, stated that there are "more services" and more specialists in public clinics than in the private system, but they lack the increased attention for the client. They can treat the disease, but they find it very difficult to care for the patient. In pure economic terms, the costs of medical services should not differ too much between state-owned and private-owned medical facilities. The relationship between the two health systems, state and private, must be characterized equally by competition and complementarity. (http://www.viata-medicala.ro/Servicii-de-S\%C4\%83n\%C4\%83tate-spi talul-public-versus-spitalul-privat.html).

For the majority of the population, the conditions of the current health care system continue to be unsatisfactory. Factors that influence the health status of the population have been described in different ways. Their grouping derives according to the concept proposed by Lalonde. In his report he argued that public health is determined not only by traditional medical care but also by four other major components: human biology, health care systems, environment, and lifestyle.

The health system in Romania is of social insurance type and aims to ensure fair and non-discriminatory access to a package of basic services for the insured. The status of insured in the health insurance system is given by the Activity Report for 2012 of the National House of Health Insurance, which states that the share in the urban area of the beneficiaries of the medical services packages included in the list of family doctors was of $94.1 \%$, and in the rural one of $74.64 \%$. Outpatient medical services, in 2015 represented $13.64 \%$ of the total expenditures on medical services, medicines and medical devices.

Thus, accessibility to health care services, according to the CNAS Annual Report for 2013 , is determined by the convergence between the supply and demand of such services, or by the actual availability of the care facilities compared to the demand based on the real need for health. Disparities in access to care appear for at least four reasons: ethnic or racial; economic, including direct costs incurred by the population (co-payments, costs related to treatment and hospitalization) as well as indirect costs (transport cost, waiting times); inadequate geographical location of care facilities; uneven quality of services of the same type.

\section{Research Methodology}

In the study we considered the following methodological aspects: the first part of the study considered an analysis of the evolutions of the medical system in Romania at regional level, 
based on secondary statistical data and in the second part of the study we considered building a model econometric to highlight the existing connections between the indicators that characterize the medical system in Romania in the regional profile. The statistical data used in the study were collected from the Tempo-Online database provided by the National Institute of Statistics, from the statistics of the National Institute of Statistics, and refers to the period 2014-2018. The main research methods used took into account the following macroeconomic variables that characterize the health and social care system in Romania in the regional profile such as: total medical-sanitary personnel (this indicator being broken down into three categories, depending on the level of studies: medical personnel with higher education, medical personnel with secondary education and auxiliary medical personnel); total number of beds, number of the hospital unit. In order to ensure a complex analysis of the links and interdependencies between the macroeconomic indicators that characterize the medical and social assistance system in Romania at regional level, the elementary methods of analysis are often insufficient.

Thus, in the study they were complemented as we have stated previously with econometric modeling methods. We performed the analysis and processing (regression, correlation, association, hierarchical methods) using the EViews and Excel database management and analysis programs. Thus, the evolution of the number of health units, as an endogenous variable can be analyzed according to the evolution of the number of beds and of the medical staff - total, factorial variables in the model.

\section{Results}

The evolution of the main medical-sanitary indicators on the development regions of Romania in the period 2014-2018

The study carried out on the 8 development regions of Romania mainly focused on five indicators whose evolution was analyzed over a period of five years, respectively 2014-2018.

The first indicator analyzed the number of hospital units is important because a potential patient must know permanently if in the region from which he comes he has sufficient hospital units, in case the person would have had to seek specialized medical care. It is also important to know if there are sufficient hospital units in relation to the number of inhabitants in each region. The analysis showed that this first indicator has not undergone significant changes in period 2014-2018. The largest number of hospital units in the period 2014-2018 was registered in the Bucharest-Ilfov and North-West regions, and the smallest number of hospital units for the same period were recorded in the South-West Muntenia and West regions, with a range between (40 -56 units). (See figure 1).

However, these last two regions have the fewest hospital units and do not have the least capacity for development from a health point of view. In the analyzed period new hospital units were built, 8 in the South West Oltenia region and 12 in the West Region, while less in regions such as the Center only 2 hospitals were built and. In other regions fewer hospital units were built, 2 in Centre Region and 3 South Muntenia Region. These discrepancies are due to the inequalities existing in the development of the regions in Romania, respectively between the less developed South and East and more deveoped NorthWest and Bucharest Ilfov regions of Romania. One of the main causes being the stronger foreign capital infusion in the North-West and Bucharest-Ilfov regions as in the rest of the Romanian regions. However, it is noticeable that there is an attempt, at the governmental level, to reduce these discrepancies, but at the moment without significant results. 
Some of the causes that lead to the creation of these significant differences are education and the research-innovation infrastructure that is very spatially concentrated, as well as the skilled workforce or the direct foreign investments as mentioned above, which were positioned in the Bucharest-Ilfov region, and the North-West Region. The main source of remediation, in accordance with the policy of the European Union, is the cohesion policy and financial resources, the so-called "smart specialization" strategy. In this context, some European specialists consider that in Romania this policy of cohesion of financial resources is closely linked to the institutional-administrative capacities of the state to implement the solutions that exist.

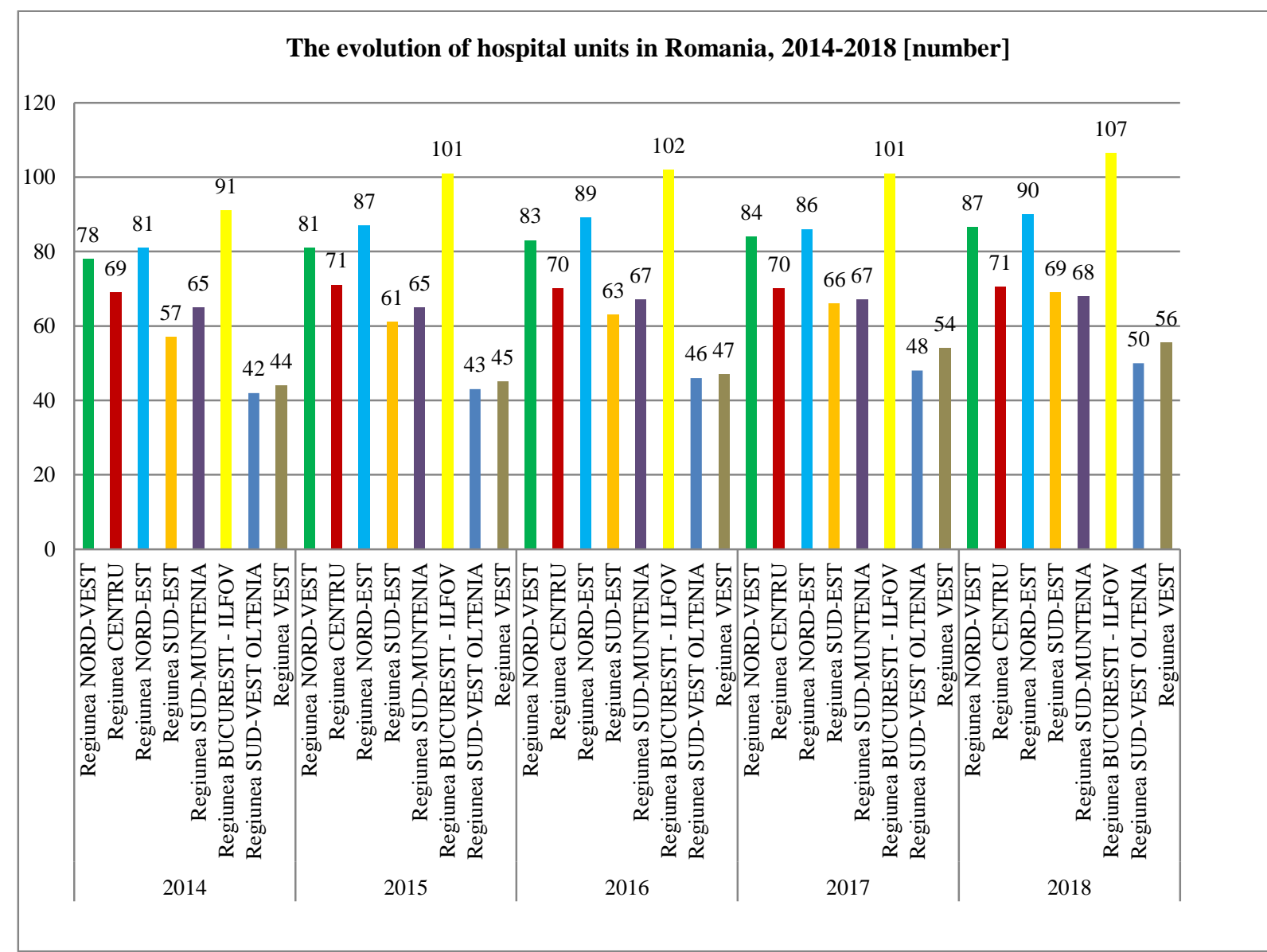

Figure 1 - Evolution of the number of hospital units in the 8 development regions, 2014-2018 Data Source: Romanian National Institute of Statistics

The second indicator considered is the number of beds. The indicator was included in the analysis because from the perspective of patients, especially those in a serious condition, it is important to have an adequate place in which to provide specialized consultation and treatment. 


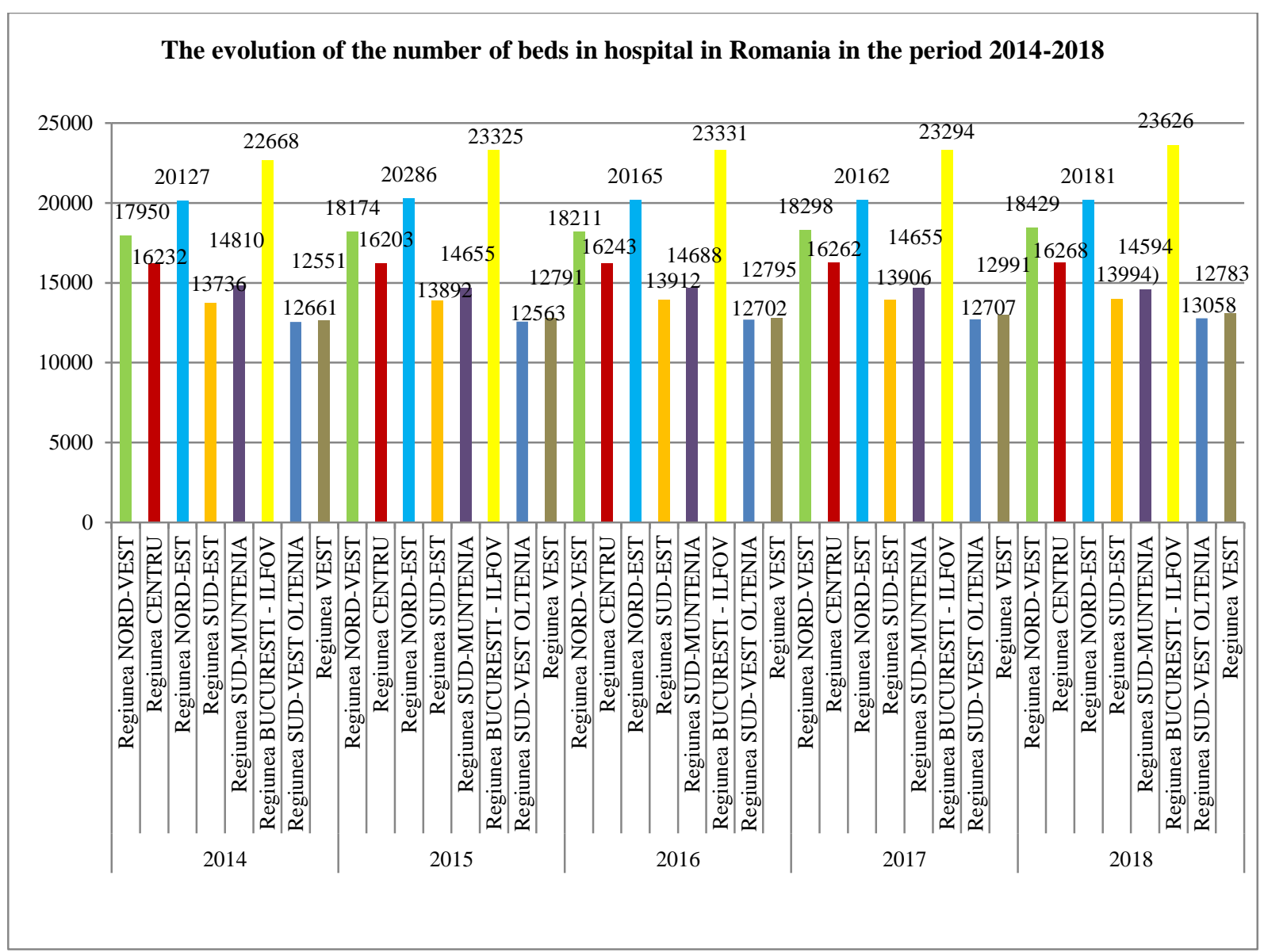

Figure 2- The evolution of the number of beds in the 8 development regions, 2014-2018 Data Source: Romanian National Institute of Statistics

It should be mentioned that both the total number of hospital beds and the number of beds available per 100,000 inhabitants, places Romania at the top of the ranking of the European Union member countries(See figure 2). Thus, during 2014-2018 it can be observed that the number of beds remained approximately constant in the Center region, but increased in the regions: North-West (from 17950 to 18174), Bucharest-Ilfov (from 22668 to 23626) , West (12551 to 12,783), North-East (20127-20181, South-East (13736-13994), South-WestOltenia (12661-13058). All these increases took into account the government policy to reduce the discrepancies between the development regions of Romania according to the directives of the Europe 2020 Strategy.

The third indicator considered in the analysis in the regional profile of the situation of the medical system in Romania took into account the total medical-sanitary personnel, defined as the totality of the specialized medical personnel who work in health care units, medical-pharmaceutical education and in units of scientific research in the medical field, both in the public and in the private sector. The sanitary personnel was divided in the following catgories: sanitary personnel with superior medical training, average sanitary personnel and auxiliary sanitary personnel, these being also the following three indicators analyzed. Starting with 1993, the medical staff includes other ministries and institutions that have their own health network, such as: Ministry of Transport, Ministry of Justice, Ministry of National 
Defense, etc. Also included is the medical staff in the units for people with disabilities. In principle, doctors study, diagnose, treat and prevent diseases, infections, injuries and other physical and mental deficiencies in humans, by applying the principles and procedures of modern medicine. They plan, supervise and evaluate the implementation of care and treatment plans by other health care providers, coordinate medical education and research activities (according to the Romanian Classification of Occupations - COR) (see figure 3).

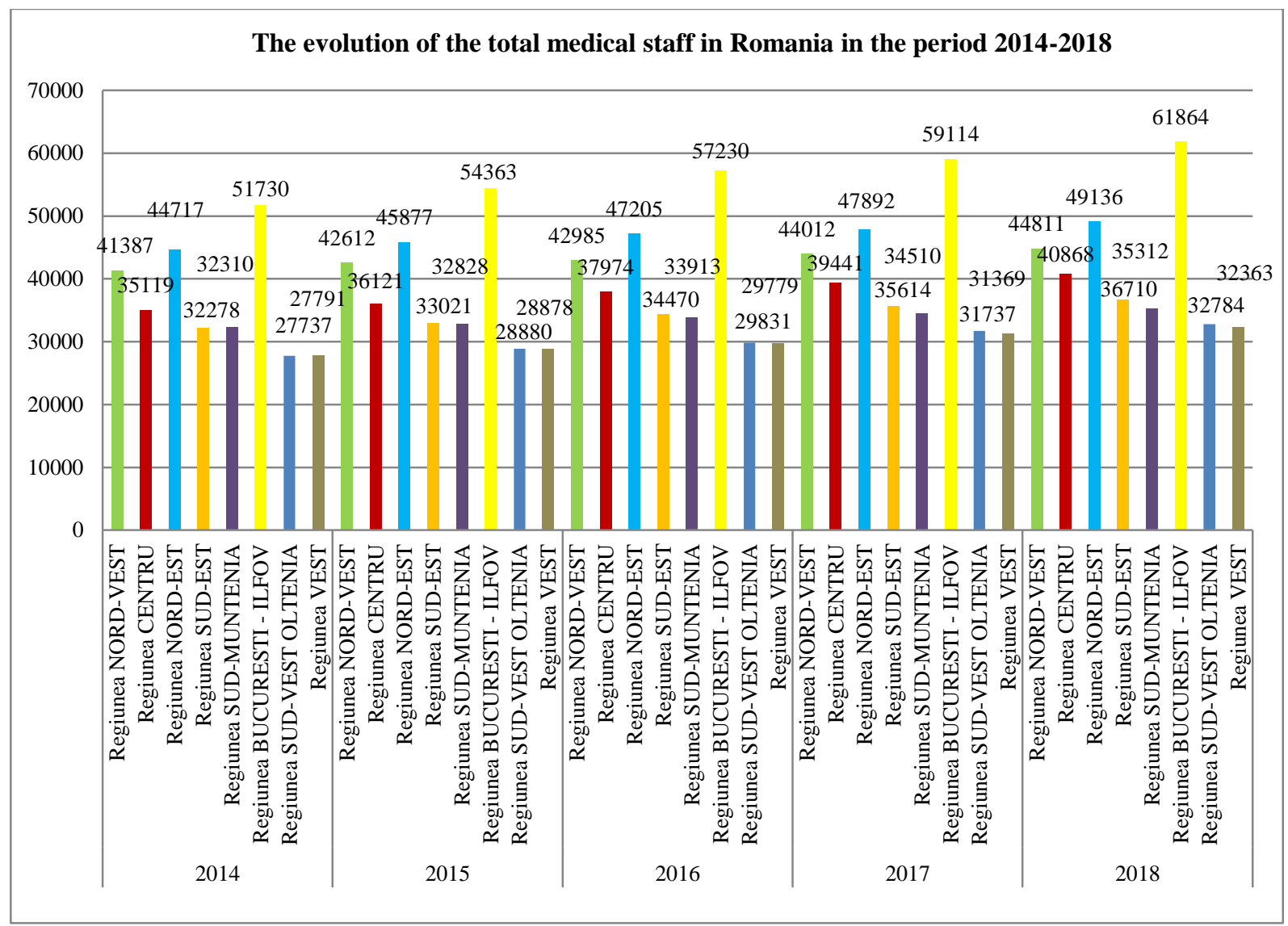

Figure 3- Evolution of the total medical-sanitary personnel on the 8 development regions, in period 2014-2018

Data Source: Romanian National Institute of Statistics

In addition to the three indicators analyzed, the work included a specific incidence on 17 disease classes in Romania, for the period 2015-2017. This analysis was performed on 100,000 inhabitants. The most widespread class of disease during the period analyzed was the disease class of the aspirator. There were 28,099 cases of respiratory tract diseases in 2015, 29.139 in 2016 and 27.088 in 2017.

Descriptive indicators that characterize macroeconomic indicators of the public health system by regions in Romania in the period 2014-2018

Following the systematization of secondary data on the health system by development regions, we further determined derived indicators (central tendency indicators, variation and asymmetry indicators, concentration indicators), which allowed us to characterize in a first phase the system activity of health in Romania between 2014-2018. (See table 1) 
Table 1 Analysis of central tendency, variation and asymmetry for the macroeconomic indicators that characterize the evolution of the health system by regions in Romania (2014-2018)

\begin{tabular}{|l|c|c|c|}
\hline $\begin{array}{c}\text { Descriptive } \\
\text { indicators }\end{array}$ & $\begin{array}{c}\text { Number of } \\
\text { hospital units }\end{array}$ & $\begin{array}{c}\text { Total medical } \\
\text { staff }\end{array}$ & $\begin{array}{c}\text { Number of } \\
\text { beds }\end{array}$ \\
\hline Mean & 70550 & 39164 & 16497 \\
\hline Median & 69000 & 35867 & 15507 \\
\hline Maximum & 107000 & 61864 & 23626 \\
\hline Minimum & 42000 & 27737 & 12551 \\
\hline Std. Dev. & 18014 & 9041 & 3588 \\
\hline Skewness & 0.170 & 0.848 & 0.664 \\
\hline Sum & 2.822 .000 & 1.566 .573 & 659.879 \\
\hline Observations & 40 & 40 & 40 \\
\hline
\end{tabular}

\section{$>$ Number of hospital units}

The average number of hospitals in Romania by development regions in the period 20142018 was about 70.55 units / region with a representativeness of $25.53 \%$. The maximum number of hospital units per development regions in Romania during the period 2014-2018 was 107 units and the minimum number of 42 units. According to the calculation of the median value, we can conclude that $50 \%$ of the development regions in Romania in the period 2014-2018 have a number of hospital units over 69 units / region, and 50\% of the regions have over 69 units / region.

\section{Total medical personnel}

Macroeconomic indicator dependent on the number of hospital units records an average value of approximately 39164 persons / region during the period 2014-2018, registering a maximum value of 61864 persons / region. The average value of the medical staff - total is a significant value because the value of the homogeneity coefficient is $(23.08 \%)$. This value of the homogeneity coefficient is due to the fact that the Romanian government has tried through its policies to reduce the discrepancies between the development regions in terms of the health system. These policies mainly focused on the following aspects: the salary increase of the medical-sanitary personnel, the increase of the number of positions in the hospital units, as well as the improvement of the working environment, the quality of the databases regarding the medical personnel etc.

\section{Number of beds}

The average value of the number of beds in 2014-2018 was about 16497 beds / region. This indicator presents a homogeneity degree of $21.74 \%$ during the analyzed period, the maximum range of variation of approximately 8120 beds / region in the period 2014-2018 is quite low which leads to an average and positive asymmetry (0.66).

Regarding the multicriteria ranking of the regions of Romania in the period 20142018, this ranking that we made within the study allowed to measure the discrepancies between the regions of Romania and to elaborate optimal development strategies. The method I used was the rank method that led to the following ranking (see table 2): 
Table 2- The multicriteria ranking of the development regions of Romania

\begin{tabular}{|l|l|c|c|}
\hline \multirow{2}{*}{ Group } & \multirow{2}{*}{ Rank } & \multicolumn{2}{|c|}{ Number of regions } \\
\cline { 3 - 4 } Small & \multirow{2}{*}{$5-8$} & $\mathbf{2 0 1 4}$ & $\mathbf{2 0 1 8}$ \\
\cline { 3 - 4 } & & $\mathbf{3}$ & $\mathbf{3}$ \\
\hline \multirow{2}{*}{ Medium } & \multirow{2}{*}{$3-5$} & (South-East, South-West, West) & (South-Est, South-West, West) \\
\cline { 3 - 4 } & & $\mathbf{2}$ & $\mathbf{2}$ \\
\hline \multirow{2}{*}{ Large } & \multirow{2}{*}{$1-3$} & (South-Muntenia, Centre) & $\mathbf{3}$ \\
\cline { 3 - 4 } & & $\mathbf{3}$ & (Bucharest- Ilfov, Nord -Vest, Nord-Est) \\
\hline
\end{tabular}

The first places are located in the Bucharest-Ilfov and North-West region, as evidenced by the evolution graph, because these two regions are the most developed in Romania. The southern region being the least developed came out last. In the capital city of Bucharest, there are large university hospitals, with specialized medical staff and highperformance medical equipment. In conclusion, in 2018, however, a slight modification of the ranking is made, namely the advancement of the Center Region from the North-East Region, a phenomenon that can be explained by the fact that this is the largest of the eight development regions of Romania, and with all they have the second highest density, respectively 101 inhabitants / $\mathrm{km}^{2}$, as well as the economic situation, namely, the GDP per capita in the region is the lowest in Romania, at about two thirds of the national average, which leads to preponderance to poor personal hygiene, low access to quality medical services, as well as to early diagnosis and disease prevention, which have as a result only the development of several classes of diseases, and therefore a national mobilization need to help the population from the area.

On the last positions are placed the South-West-Oltenia region, respectively the West region, regions that are positioned at opposite poles when it comes to economic development, are now in the same area due to the fact that it has a low population density per $\mathrm{km}$, so does not require a large number of hospital units, implicitly an increased number of indicators analyzed. We appreciate that the hierarchy of the development regions in Romania, based on the rank method, led to a hierarchy in accordance with the reality.

\section{Analysis of the dependence between the macroeconomic indicators that characterize the public health system by regions in Romania in the period 2014-2018}

To investigate the existence / absence of a connection between the aforementioned indicators in the study, we developed a multiple linear regression model. Within the model, we considered the number of hospital units as a dependent variable and the number of beds and medical staff - total as independent variables. Econometric modeling considered: developing the regression model, estimating the model parameters and checking the accuracy of the results. From the correlation graph, it turned out that the points in the graph network (Figure 4) are uniformly distributed, without disparities between them, so we can conclude that the link between the independent variables that characterize the health system in Romania by development regions and the number of hospital units as a dependent variable it is linear, direct and significant. 


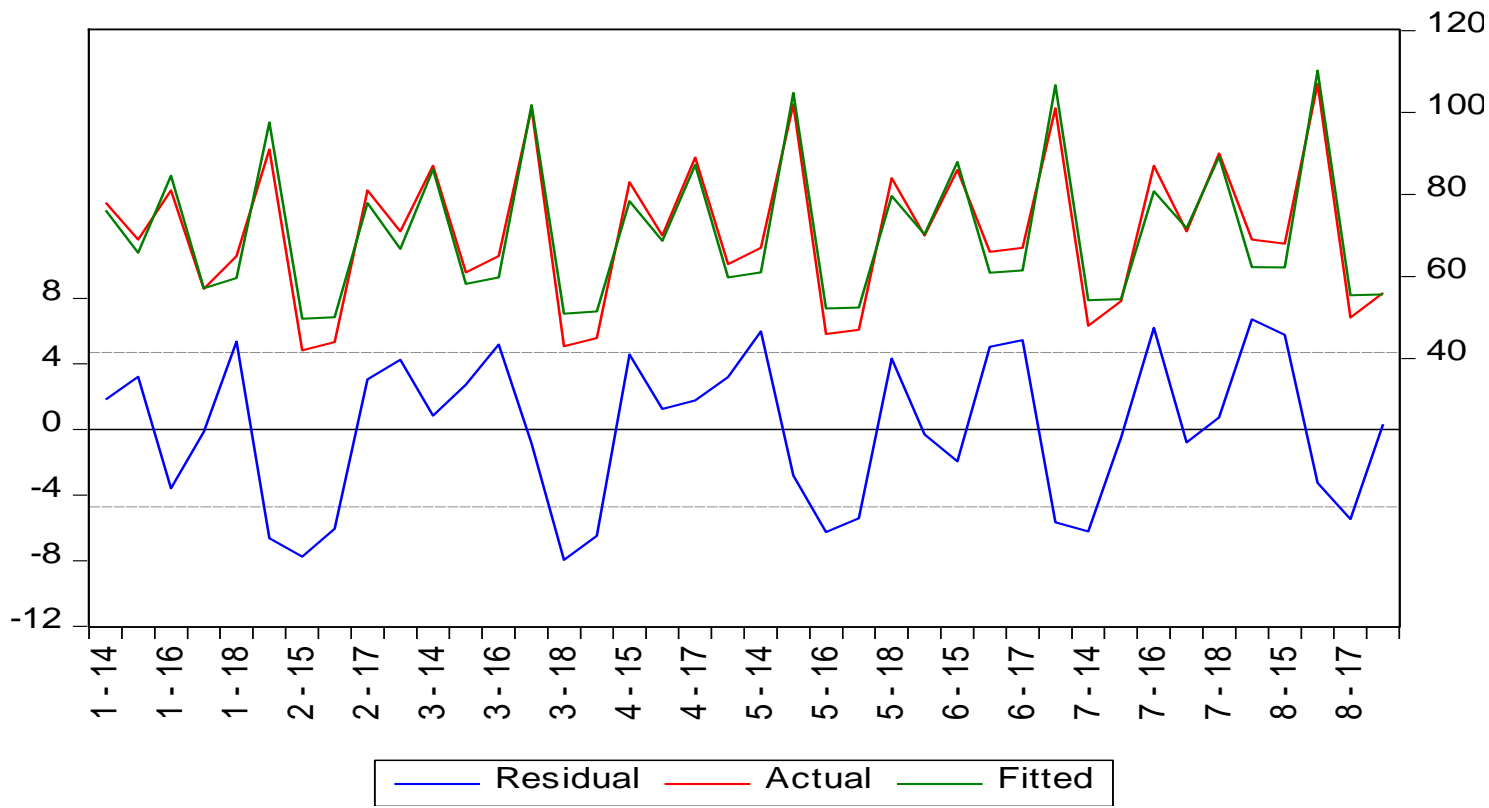

Figure 4. Actual, Fitted, Residual Values

Source: Authors' own research

By exemplifying the multiple linear regression model, using the EViews software package, we obtained in the study the following results of the multiple regression function, using the multifactorial linear regression model (see table 3):

$$
\hat{y}_{\text {numberofhospital }}=-7.568+0.001 \text { bedshosp }+0.002 \text { medstaff }
$$

Using the known statistical tests to verify the significance of the model parameters (Student's test), the significance of the model and the OLS hypotheses, we found that the estimation results and the model were statistically significant for a significance level of 5\% for all the independent variables included in the model. . The multiple correlation report resulting from the econometric model whose value is 0.96 , suggests that the link between the variables included in the model is linear, significant and direct. The coefficient of determination shows that $93 \%$ of the variation of the hospital units by development regions is explained by the influence of the variables the medical personnel - total and the number of beds, also showing the adjusted $\mathrm{R}$ indicator, but taking into account the number of degrees of freedom. The validity of the multifactorial regression model and the multiple correlation report based on the "Fisher" criterion led to the following conclusion: because the probability of Sig. F is less than 0.05 . The multifactorial regression model is significant, i.e. valid, as is the multiple correlation ratios for a significance threshold of 0.05 . Thus, we appreciate that, the independent variables included in the model have a significant influence over the variation of the dependent variable (the number of hospital units) contributing to the average annual growth of this macroeconomic indicator. OLS assumptions are checked for the same significance level, except for the error autocorrelation hypothesis, tested using the DurbinWatson test. 
Table 3. Multiple correlation between the number of hospital units as dependent variable and total medical staff, number of beds as independent variables at the level of development regions of Romania

\begin{tabular}{|c|c|c|c|c|}
\hline \multicolumn{5}{|c|}{$\begin{array}{l}\text { Dependent Variable: Number of hospital units } \\
\text { Method: Panel Least Squares } \\
\text { Date: } 07 / 19 / 19 \text { Time: } 17: 11 \\
\text { Sample: } 20142018 \\
\text { Cross-sections included: } 8 \\
\text { Total panel (balanced) observations: } 40\end{array}$} \\
\hline Variable & Coefficient & Std. Error & t-Statistic & Prob. \\
\hline $\begin{array}{l}\text { C } \\
\text { Total medical staff } \\
\text { Number of beds }\end{array}$ & $\begin{array}{l}-7.568734 \\
0.001027 \\
0.002297\end{array}$ & $\begin{array}{l}3.584325 \\
0.000379 \\
0.000955\end{array}$ & $\begin{array}{l}-2.111621 \\
2.709556 \\
2.404067\end{array}$ & $\begin{array}{l}0.0415 \\
0.0101 \\
0.0213\end{array}$ \\
\hline $\begin{array}{l}\text { R-squared } \\
\text { Adjusted R-squared } \\
\text { Log likelihood } \\
\text { F-statistic } \\
\text { Prob(F-statistic) }\end{array}$ & $\begin{array}{l}0.935194 \\
0.931691 \\
-117.1703 \\
266.9693 \\
0.000011\end{array}$ & \multicolumn{2}{|c|}{$\begin{array}{l}\text { Mean dependent var } \\
\text { S.D. dependent var } \\
\text { Hannan-Quinn criter. } \\
\text { Durbin-Watson stat }\end{array}$} & $\begin{array}{l}70.55000 \\
18.01417 \\
6.054311 \\
1.508884\end{array}$ \\
\hline
\end{tabular}

Source: Authors' own research

OLS assumptions are checked for the same significance level, except for the error self-correction hypothesis, tested using the Durbin-Watson test. Statistically, DW recorded a calculated value DW $=1.50$, a value that we compared with the critical statistical values for $\alpha$ $=0.05, \mathrm{p}=2$ and $\mathrm{n}=40 ; \mathrm{d} 1=1.62$ and $\mathrm{d} 2=1.72$ suggest that the errors are positively correlated. The Jarque-Berra test (see Figure 5) has a test value JB $=3.04 ; \chi$ and that $\mathrm{p}(\mathrm{JB})=$ 0.21 we consider that, the error normality assumption can be accepted.

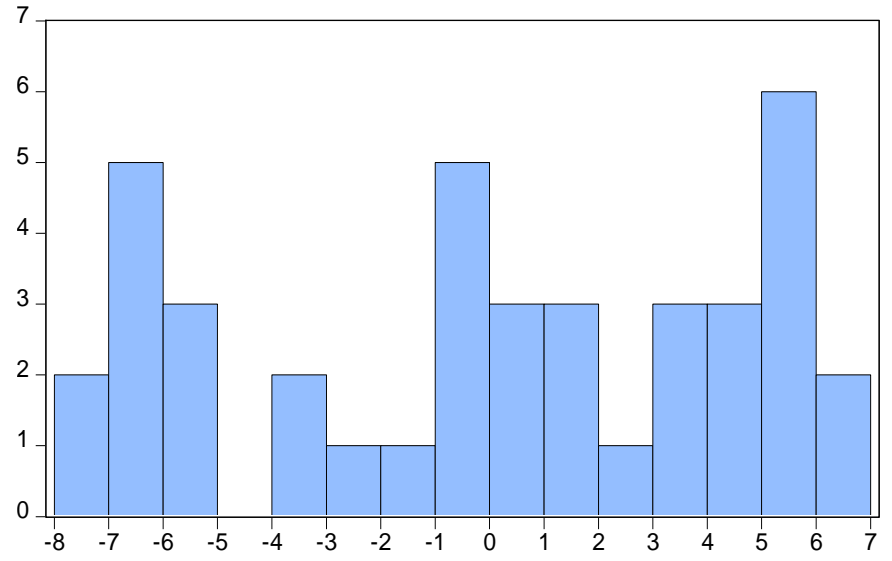

$\begin{array}{ll}\text { Series: Standardized Residuals } \\ \text { Sample 2014 } 2018 \\ \text { Observations } & 40 \\ & \\ \text { Mean } & 4.11 \mathrm{e}-15 \\ \text { Median } & 0.540278 \\ \text { Maximum } & 6.719683 \\ \text { Minimum } & -7.950636 \\ \text { Std. Dev. } & 4.585856 \\ \text { Skewness } & -0.249580 \\ \text { Kurtosis } & 1.742704 \\ & \\ \text { Jarque-Bera } & 3.049926 \\ \text { Probability } & 0.217629\end{array}$

Figure 5. Distribution of the normality of the errors

Source: Authors' own research

In conclusion, while the demand for medical and social care services is showing an upward evolution, the medical services at the local level, as well as the non-governmental ones for intervention by types of illnesses are still insufficiently developed in terms of 
diversity and from the point of view of qualitative view.

\section{Conclusions and recommendations}

The health status of Romanians has improved, but life expectancy at birth remains among the lowest in the European Union. Although people live longer, coverage is not universal, and socio-economic inequalities in health persist. The reform of the health system has been constant, but frequently inefficient, partly because of a high degree of political instability and lack of funding.

The degree of development and dissemination in the territory of the sanitary infrastructure, the insurance with medical personnel, the conditions for the provision of health services, as well as the distribution and use of financial resources, are factors that highlight and at the same time influence the offer of the health system. in the field of health care. (Panait, Carmen Lavinia, 2011, p.16). In this context, following the study, it has been shown that there are quite significant differences between the eight Romanian development regions regarding the functioning of the public health system. Also, these differences were highlighted and the main reasons that led to their appearance were presented. The analysis revealed that the South-West Region, respectively the West region - two regions that are positioned at opposite poles in the general context of economic development - are now in the lower part of the hierarchy based on the indicators of the health system. This is due in mainly to a relatively low density of inhabitants; therefore, the need for hospital units is less acute. Increasing the efficiency and effectiveness of medical service organizations and enhancing the provision of high-performance services are now conditioned, more than ever, by the use of information and communication technology (Zamfir, 2011, p.389). When using the Internet, service organizations have two options: to offer generalized services, at low prices or to offer services very adapted to the needs of the beneficiaries, at higher prices. In conclusion, the more efficient and widespread use of information and communication technology at the regional level, as well as an infusion of foreign capital in the less developed areas, would lead to the reduction of the health system disparities in Romania at regional level. Equalizing employee income at the regional level could be a way to reduce discrepancies.

\section{References:}

Anghelache, C. (2008) „Tratat de statistică teoretică și economică”, Bucharest, Editura Economică.

Constantin, D. L. (2004) „Elemente fundamentale de economie regională”, Bucharest, Academy of Economic Studies.

Eurostat. Politica de sănătate în Uniunea Europeană. Preluat de pe ec.europa.eu: http://ec.europa.eu/eurostat/web/health/overview.

Institutul naţional de Statistică. Sănătate. Preluat de pe tempo: http://www.insse.ro/cms/ro/content/indicatori-de-statistica-regionala-tempo.

Lalonde M. (1974) “A New Perspective on the Health of Canadians”. Ottawa, Ontario, Canada: Minister of Supply and Services; 1974.

OECD-UE (2017). România. Profilul Sănătătii în 2017.State of Health in the U.E. Retrieved February20 2018, from https://ec.europa.eu/romania/news/20172311.

Major, D. (2009) Asigurari sociale în România. Realităţi şi perspective ed. Cărţii de ştiinţă Cluj Napoca

Panait, C. L. Oferta vs cererea de servicii de sănătate în contextul demografic actual din România , Revista Management în sănătate, XV/4/ 2011,14-16. 
Stoina , N.c (2012),, MANAGEMENTUL REFORMARII SISTEMULUI DE SANATATE PUBLICAfundamente teoretice si pragmatism, MANAGEMENT IN HEALTH, VOL 16, NO 1 (2012), 4-13

Zamfir, A. (2011). Managementul serviciilor. Bucharest: Ed. ASE,389.

http://appsso.eurostat.ec.europa.eu/nui/show.do?dataset=hlth_sha11_hf\&lang=en [Access to date de 25.05.2019].

http://appsso.eurostat.ec.europa.eu/nui/submitViewTableAction.do [Access to date 25.05.2019].

http://appsso.eurostat.ec.europa.eu/nui/show.do?dataset=demo_mlexpec\&lang=en [Áccess to date 30.06.2019].

http://gov.ro/ro/obiective/strategii-politici-programe/sanatate\&page=1\#null [Access to data la date de 31.06.2019]

http://www.iccv.ro/Institutul de cercetare a calităţii vieţii [Access to date de 31.06.2019]

https://ec.europa.eu/romania/news/20172311_profil_sanatate_state_membre_si_ue_ro [Access to date de 31.06.2019]

http://gov.ro/fisiere/pagini_fisiere/PROGRAMUL_DE_GUVERNARE_2018-2020.pdf[Access to date de 31.06.2019]

http://www.cjasis.ro/W_CAS_IS/cas/raport_activitate/CAS\%20IASI\%20RAPORT\%20ACTI VITATE\%202017.pdf[Access to date de 31.06.2019] 